\title{
SYPHILIS IN SEVENTEENTH CENTURY LANCASHIRE
}

There have been found recently among the archives of the Court of Quarter Sessions in the Lancashire County Record Office, Preston, two petitions which cast light on the incidence of syphilis in the seventeenth century. It should be explained that until the year 1889 the administration of a county was almost entirely under the control of the Justices of the Peace. Usually the actual work was done by such local officers as the churchwardens, parish constables, overseers of the poor and surveyors of the highways ; but if these people - who were elected to serve the office annually-neglected their duty, or if any difficult or unusual problem arose with which they could not cope, appeal could be made to the Justices in their Court of Quarter Sessions. It is such appeals, or petitions, to which attention is now drawn.

The first (QSP.56/6) was addressed to the Quarter Sessions held at Manchester in October 1651, and reads as follows :

"To the Right Worshipful Justices of the Peace and quorum for the County pallatyne of Lancaster.

Right Worshipfulls

This may bee to acquaynt you that their is a pore yong woman in our Towne of Asshtonunderlyne infected with a filthy deceassed called the French poxe and shee saith shee was defyled by one Henry Heyworth a maryed man, but soe it is the report of that dessease occasioneth neighbors to deny hir harbour and shee is enforced to lye in the streetes and in great danger to bee starved, I do humbly intreate your worshipps to take it into your consideration and to grant your Order that thelpore woman may bee provyded for to prevent starveing, either uppon the parrish charges, or uppon the Costs of the said Heyworth whom shee saith hath spoyled hir, whether yiur worshipps shall thinke fitt.

[Order of the Court] To erect some small cottage or Cabin for her in regard to her lothsomenes."

The magistrates apparently threw the expense of the maintenance of the infected girl upon the township. The most interesting feature is the isolation which was ordered. Part of Lancashire was at the time in the throes of an outbreak of plague, which had troubled the county much since the beginning of the century (France). Under an Act of 1603 isolation for plague became compulsory, and the powers given to combat plague were used, in this Ashton-under-Lyne instance, to deal with a case of syphilis. The fact that it was considered to be necessary to approach Quarter Sessions would seem to indicate the rareness of the disease.

Another petition which showed the incidence of syphilis was presented to the Preston Quarter Sessions in October 1695. (QSP. 769/3).

“ To the Right Worshipfull his Majesty's Justices of the Peace at the Quarter Sessions at Preston.

The humble Peticion of Thomas Clarkson of Whittingham, husbandman.

Sheweth,

That about 4 or 5 yeares agoe one of your Petitioners Daughters was harboured by some of the Romish Perswasion in the Towne of Haighton and was by them or some Irish men (who had formerly been soldiers under the late King James) drawne into such a height of debauchery that shee gott thereby the Pox commonly called the French pox and tho your petitioner would have had her to remove out of the Towne and to leave off her debauched company, yett was shee perswaded still to continue therein. And your peticioner in getting remedyes for his said daughter's distemper is now reduced to that low estate as he is scarce able to mantayne himself much lesse his now wife and 5 children by a first wife. And your peticioner being very poore, his Debts being extraordinary and sued almost every day,

Humbly craves that the said Towne of Haighton where he was borne and hitherto lived may be enforced to receive and provide for two of your Petitioner's Childrene vizt. Ellene and Thomas his son and Daughter, and the 'rest your petitioner with his owne industry will endeavour to his utmost power to mantayne without any charge to the said Towne. And your petitioner as in duty bound will ever pray, etc."

The first application seems to deal with a case of fresh syphilitic infection. It is interesting to note the general hostility of the people towards the infected person. That might be explained partly by the fact that syphilis was very rare in the provinces at that time, and partly by the political regime of the time. According to Pepys' Diary, some time later, during the Restoration, syphilis was regarded in London more as a matter of course (Rolleston). 
The second application deals with an old case of infection, and the existence of syphilis seems to be used only to support the application for financial benefit. It touches the problem of spreading venereal diseases by demobilized soldiersa problem which is still as important as it was when it first became known, at the beginning of the sixteenth century.

For permission to publish this paper we are indebted to Mr. R. H. Adcock, Clerk of the Lancashire County Council, and to Dr. F. Hall, County Medical Officer of Health.

\section{REFERENCES}

France, R. Sharpe (1939) Trans. Hist. Soc., Lancs. and Cheshire, 90, 11. Rolleston, J. D. (1943) Brit. J. vener. Dis., 19, 169.

\section{GENITAL OEDEMA IN RELATION TO FILARIASIS IN THE GOLD COAST}

Between June and September 1944 there were 875 African soldiers admitted to the 37th General Hospital at Accra in the Gold Coast. Of these there were 10 who showed genital oedema in which filariasis was suspected. The oedema affected the penis in all of these patients and the scrotum also in 7 of them. On each an examination was made for microfilariae, by means of a day-and-night blood film to detect blood-borne varieties, and of the taking of a small skin scraping from the inner aspect of the thigh to detect the lymphatic-borne embryos of Onchocerca volvulus. In addition a blood count was done for the detection of eosinophilia.

Parasites were demonstrated in 7 of the patients, of whom 5 showed the microfilariae of Loa loa in the blood and one had microfilariae of Acanthocheilonema perstans; in another the existence of onchocerciasis was proved by the skin scraping.

\section{Loa loa}

Of the 5 cases with Loa loa infection, 3 had had attacks of genital oedema during the past 3 years, and all denied-probably falsely-recent sexual intercourse. One was undergoing arsenical treatment for syphilis, but none had active venereal disease at the time of examination. All the patients had swelling of the penis. Two had also gross scrotal oedema, the scrotum reaching the size of a grape-fruit in each case, and in another there was a hydrocele. In all these cases the skin scrapings gave negative results, but in 3 of them an eosinophilia between 15 and 20 per cent was found.

Treatment was by means of a suspensory bandage, and in 4 cases the attack subsided within a week and the men were discharged from hospital. In the case of the fifth patient, who had both penile and scrotal oedema, the surgeons performed an operation, removing the elephantoid skin of the penis and scrotum, transplanting the testicles into the thighs, and restoring the appearance of the penis by a skin graft. The immediate results of this procedure were very satisfactory.

\section{Microfilariae perstans (Acanthoceilonema perstans)}

The man infected with microfilariae of $A$. perstans had very well marked oedema of both penis and scrotum and, although the patient denied sexual intercourse during the previous 4 months, there was an associated acute gonococcal urethritis. There was no eosinophilia and nothing abnormal was seen in the skin scraping, but the microfilariae perstans were readily demonstrated in the blood. The patient did not give any history of a previous attack, but, in view of the severity of this 